\title{
NATURAL SCIENCE EDUCATION IMPORTANCE IN ADOLESCENCE
}

\author{
Vincentas Lamanauskas \\ University of Siauliai, Siauliai, Lithuania
}

\begin{abstract}
Natural science importance is indubitable. Research studies of the last few decades confirm such position. Science education has been frequently accepted as an inseparable and extremely important part of comprehensive schooling (Lamanauskas, 2008). By natural education we seek personality maturity in a wider sense. It would seem that everything is said concerning this question. However, it is not so. Rapid spread of scientific cognition inevitably raises new challenges for natural education, induces to re-evaluate generally used education strategies and methodologies. There is a rapid development of $\mathrm{ICT}$; their penetration into educational environments is really intensive, though not always adequate to the raising educational goals. On the other hand, our understanding about human brain activity and possibilities is extending. Generally speaking, neuroscience opens new opportunities for people. Even though it is firstly connected with treatment, new treatment methods, on the other hand, the achievements in this field have a great influence on education. Scientists actively investigate changes taking place in human brain, for example, committing memorization process. In other words, while a person is learning, different physical, chemical, biological changes take place in his brain (Perkins, 2013). As researchers notice, each student brings a unique personal neural history to school every day, which gives teachers quite a challenge as they try to customize learning for each student (Trnikova, 2013). After all, neuro-linguistic programming can also considerably help to develop teaching/learning process. Quite often it happens that teachers apply such teaching ways and methods which most frequently correspond to their own teaching style. However, it does not mean, that such approach is compatible with the learners' learning needs, possibilities, style and so on. In this context, the moment of teacher's skillfulness is much more expressed, which is inseparable from educational effectiveness. And, what is more, XXI century requires different pedagogy, in this regard, natural science neuro pedagogy. Exhaustive scientific research studies are necessary in this direction.
\end{abstract}

Thus, a short glimpse of some natural science education moments makes us concentrate our attention to adolescence period in human's life. There is no aim here to exhaustively define adolescence age boundaries; however, according to practice existing in many countries, it comprises the pupils from grades 5 to9 (about 10/11-15/16 years of age). It is understandable, that adolescence age boundaries are conditional. It is obvious, that teachers face a dilemma how to behave with a teenager - to treat him like an adult or like a child? Speaking about natural science education, it is understandable, that the pupils of this age already have a certain natural education, they have finished primary school. Giving general evaluation, one can claim, that their interest in natural sciences and motivation, mastering natural science knowledge and forming abilities at the period of primary school, do not raise any important problems. However, motivation changes later. It would be untrue to claim that motivation decreases. It just alters. Adolescence period is marked by acceleration, a certain adolescence crisis, the problems of the ability to think in an abstract way, increased emotionality, strengthening individualism and so on. In other words, the main question for the teenager becomes "What am I?" On the other hand, more active personality development is observed. Teenagers seek 
to be themselves, communicate with as many different people as possible, try themselves in different activities, to realize themselves and so on. However, the problem is not here. The problem is in the fact, that in many cases natural science education at that age period is realized between four class walls. Self-expression possibilities are rather limited. It is natural, that teenagers are looking for the other ways of self-expression, their motivational and value structure changes.

Natural surrounding is full of irritants, which directly determine teenagers' activity motivation. It should be sought, that their integral influence was used for the mature personality formation. Teenagers' insistence in respect of educators also immensely changes in this period of time. Thus, pedagogical competence is cornerstone. Nature subject teachers should be able to find the most optimal ways of natural science education process organization. This requires big efforts of educators and quite often nontraditional pedagogical decisions as well. In adolescence period, one of the most essential moments is to hold and further strengthen pupils' interest in natural sciences. Estimating various international research results, first of all, ROSE (The Relevance of Science Education, 2013), one can claim that this is, undoubtedly, primary educators' task. It means that it is important to teach perceive the acquired knowledge and be able to apply it in real life situations, create and model, independently carry out various practical tasks, search for information in various sources and be able to analyze, systemize and estimate it. Estimating adolescence context, it is necessary to make conditions for children to give themselves to natural, quite often spontaneous creation impulses. Natural science subjects should be given through the investigation process and not through factological approach, when the most important thing is to learn, that is, to master by memory. Discussions, stimulation of mental activity, reflections become of great importance. The compatibility of formal and informal educational surroundings is a very significant moment in this period. It is obvious, that formal school is not capable of providing all possibilities because of various objectively restricting factor influences. However, it is necessary to search for optimal conformity of these mentioned surroundings. These can be various clubs, young naturalist summer camps, clubs, nature and technology museums' educational activity, expeditions and other. In adolescence stage, research, creative and project works become extremely important. Forming pupils' cognitive and practical abilities, such works should become the central part of natural science education. The format of their organization and carrying out can be various as well.

Modern and future ICT are inevitably opposition to natural surroundings. Their importance is not denied, however children (and especially teenagers) are intensively interested in these technologies, the latter occupy not a small part of their life. This is not necessarily directly related with learning at school. It is understandable, that school surrounding and teaching process itself are, as a matter of fact, saturated with different technologies. Today's physics, chemistry or biology lesson cannot be imagined without ICT (digital teaching/learning content, digital means, interactive and virtual demonstrative and experimental tests, various computer visualizations and other). In the same way, there is plenty of research, showing the effectiveness of ICT appliance, achievable better learning results. However, the question remains open - whether interactive and virtual natural science education can indeed change the classical one, when real tests, experiments, observations are performed. In other words, natural education takes place in natural surroundings maximally using current possibilities and searching for the new ones. It is paradoxical, natural science education ICT- zation increasing, very distinct natural science unpopularity is observed in the teenagers' population. It is claimed quite often, that ICT appliance in natural science lessons gives a chance to virtually carry out all experiments and tests when there are no proper conditions to carry out them realistically. This is a conditional thing. Very easy and fast ICT appliance does not encourage, in a way, to search for these proper conditions.

In any case, the teacher solves the whole lot of dilemmas and contradictions. Pupils are always different, individual. Teenagers' individualism is very much expressed. Some of them are getting interested and are interested in a concrete activity, while the others are waiting and can't wait for the end of the activity. It is obvious, that natural education in adolescence is, as a matter of fact, situational, integral and flexible. The main factors leading to teacher's success are creativity, skillfullness and erudition. 


\section{References}

Lamanauskas V. (2008). Gamtamokslinis ugdymas mokykloje - neatsiejama bendrojo ugdymo dalis / Science Education at School - an Inseparable Part of General Education. Kn.: Gamtamokslinis ugdymas bendrojo lavinimo mokykloje - 2008 (XIV nacionalinès mokslinès-praktinès konferencijos straipsnių rinkinys, Utena, 2008m. balandžio mèn. 25-26 d.). Šiauliai: Lucilijus, p. 5-8.

Perkins, R. (2013). What do memories look like? USC News. Retrieved 05 August 2013, from http://news.usc.edu/\#!/ article/52496/what-do-memories-look-like/

The Relevance of Science Education (ROSE). Retrieved 05 August 2013, from http://roseproject.no/

Trnikova, J. (2013). Brain-based learning strategies and inclusive education. Technologia Vzdelavania / Technology of Education, 3, 7-9.

Received: June 30, 2013

Accepted: August 05, 2012

\begin{tabular}{|cl|}
\hline Vincentas & PhD, (HP), Professor, Natural Science Education Research Centre, \\
Lamanauskas & University of Siauliai, 25-119 P. Višinskio Street, LT- 76351, Siauliai, \\
& Lithuania. \\
& E-mail: lamanauskas@lamanauskas.puslapiai.It \\
& Website: http://www.lamanauskas.puslapiai.It/ \\
\hline
\end{tabular}

